BONAFIDE: Jurnal Teologi dan Pendidikan Kristen

www.jurnal.sttissiau.ac.id/Volume 2/Nomor 1/Juni 2021/hal. 46-67

\title{
PERGESERAN MAKNA ALKITAB SEBAGAI KITAB SUCI PADA KAUM MUDA PENGGUNA ALKITAB DIGITAL DI LUWUK
}

\author{
Ermin Alperiana Mosooli, Onal Amalakon, Alfionita Sumuding \\ Sekolah Tinggi Teologi Star's Lub Luwuk Banggai \\ ermin21.1973@gmail.com
}

Diterima tanggal: 21-06-2021

Dipublikasikan tanggal: 26-06-2021

\begin{abstract}
This paper aims to find out the shift in the meaning of the sacredness of the Bible from the book version of the Bible to the digital version of the Bible among young people who use digital Bibles. The research method is a comparative study of quantitative methods. The control variables used are the Bible content and the Bible media. The research subjects are young digital Bible users aged 18-35 years in Luwuk, Banggai, Central Sulawesi. The data was taken by survey technique involving 26 respondents. The results showed a significant shift in the meaning of the scriptures in the media variable, while there was no significant shift in the content variable. Thus, the research result can conclude that the book version of the Bible is more sacred for respondents both in content and media, but the digital version of the Bible is sacred in its contents only.
\end{abstract}

Keywords: the Bible, the digital Bible, the sacredness of the Bible, young people

\begin{abstract}
Abstrak. Tulisan ini bertujuan untuk mengetahui pergeseran makna kesucian Alkitab dari Alkitab versi buku kepada Alkitab versi digital di kalangan anak muda pengguna Alkitab digital. Penelitian dilakukan dengan studi komparatif pada metode kuantatif. Variabel kontrol yang digunakan adalah variabel isi Alkitab dan variabel Alkitab. Subyek penelitian adalah kaum muda pengguna Alkitab digital berusia 18-35 tahun di kota Luwuk, Banggai, Sulawesi Tengah. Data diambil dengan teknik survey dengan melibatkan 26 responden. Hasil penelitian menunjukkan bahwa pergeseran makna kitab suci secara signifikan terjadi pada variabel media, sedangkan pada variabel isi tidak terjadi pergeseran signifikan. Dengan demikian dapat disimpulkan bahwa bagi responden Alkitab versi buku lebih suci baik pada isi maupun media, namun Alkitab versi digital yang suci hanyalah isinya.
\end{abstract}

Kata-kata kunci: Alkitab, Alkitab digital, kesucian Alkitab, anak muda

\section{PENDAHULUAN}

Saat ini penggunaan Alkitab versi digital sudah mulai banyak digunakan di kalangan umat Kristen. Sebuah hasil penelitian di Amerika tahun 2017 menemukan 
BONAFIDE: Jurnal Teologi dan Pendidikan Kristen

www.jurnal.sttissiau.ac.id/Volume 2/Nomor 1/Juni 2021/hal. 46-67

bahwa meskipun $91 \%$ responden masih memilih Alkitab tercetak, namun membaca Alkitab melalui media digital juga mengalami peningkatan. Mereka mencari ayat Alkitab secara online (55\%), mendengarkan Alkitab melalui podcast atau audio 36\%, dan 43\% menggunakan aplikasi Alkitab di smartphone (Susanto 2018).

Di Indonesia sendiri masih sulit mendapatkan hasil penelitian mengenai penggunaan Alkitab digital. Namun Jery Sumampow mengemukakan bahwa "Dulu gereja resisten dengan Alkitab elektronik, tetapi kini hampir semua pemilik gawai memiliki Alkitab, juga Kidung Jemaat atau NKB digital dalam gawainya" (Berita Oikumene 2016). Lembaga Alkitab Indonesia (LAI) yang merupakan penerbit Alkitab tingkat nasional yang diakui oleh hampir semua gereja di Indonesia terus berinovasi dengan Alkitab versi digital. Harsiatmo Duta Pranowo, sekjen Lembaga Alkitab Indonesia (LAI) menjelaskan hal tersebut merupakan upaya untuk menyesuaikan dengan perkembangan yang ada. Beliau mengatakan, "Zaman berubah, namun firman Tuhan tidak berubah, kebenaran firman Tuhan harus disampaikan"(Berita Oikumene 2016). Hal ini sejalan dengan pengakuan bahwa Alkitab sendiri telah mengalami banyak perubahan fisik dalam waktu yang sangat panjang, mulai dari bahan papirus dan perkamen, bahan kertas, hingga yang terbaru saat ini dalam bentuk digital elektronik (Klasis GPM Kota Ambon 2019).

Kehadiran Alkitab versi digital tampaknya telah mengakibatkan "popularitas Alkitab fisik yang legendaris ini semakin menurun." Salah satu pertanyaan yang muncul dari itu, "apakah Alkitab digital akan menggantikan posisi Alkitab fisik seutuhnya?" (Klasis GPM Kota Ambon 2019) Tampaknya ini bukan hal yang 
BONAFIDE: Jurnal Teologi dan Pendidikan Kristen

www.jurnal.sttissiau.ac.id/Volume 2/Nomor 1/Juni 2021/hal. 46-67

mustahil mengingat derasnya perkembangan teknologi informasi yang menyerbu, memasuki, dan merasuki seluruh sendiri kehidupan masyarakat, termasuk gereja. Meskipun masih ada sebagian orang yang resisten terhadap penggunaan Alkitab digital tapi sulit dibayangkan bahwa di masa akan datang resistensi tersebut akan tetap bertahan.

Ada beberapa alasan orang Kristen menggunakan aplikasi Alkitab. Chen mencatat alasan tersebut antara lain: 1) Alkitab dalam bentuk aplikasi dengan berbagai terjemahan bahasa sangat mempermudah, 2) dapat diakses tanpa terbatas oleh ruang dan waktu, 3) lebih efisien, 4) tidak perlu harus membawa buku tebal (Chen 2019).

Maryanti juga mengemukakan keunggulan lain yang membuat orang semakin menyukai penggunaan Alkitab digital: Pertama, ukurannya yang cukup kecil membuatnya mudah dibawa. Tidak berat dan tidak ribet, bisa dimasukkan dalam tas atau saku dengan mudah. Kedua, membaca dan merenungkan firman Tuhan bisa dilakukan kapan saja sepanjang ada smartphone. Ketiga, sangat memudahkan melakukan pencarian suatu kitab, pasal, ayat, bahkan sebuah kata kunci dalam sesisesi pembelajaran Alkitab pun. Penggunaannya semudah menggunakan kalkulator. Untuk mendapatkan hasil tinggal menekan beberapa tuts dan keluarlah hasilnya. Keempat, bagi yang senang ber-social media, Alkitab digital memudahkan mereka berbagi renungan di media sosial. Hanya dengan memberikan sentuhan pada aplikasi maka dalam hitungan detik, ayat yang ingin dibagi sudah langsung terkirim. Kelima, beberapa orang lebih memilih alkitab digital dengan alasan font yang lebih besar, 
BONAFIDE: Jurnal Teologi dan Pendidikan Kristen

www.jurnal.sttissiau.ac.id/Volume 2/Nomor 1/Juni 2021/hal. 46-67

karena kesulitan membaca buku Alkitab dengan ukuran yang tercetak terlampau kecil (Maryanti 2015).

Apakah penggunaan Alkitab digital bisa mempengaruhi kualitas iman seseorang? Chen mengemukakan pendapat orang diwawancarainya yang menyatakan dengan tegas bahwa "hal itu tidak mempengaruhi iman seseorang" (Chen 2019). Buktinya para pengguna Alkitab digital selalu menggunakannya baik dalam kegiatan ibadah maupun di luar ibadah. Artinya mereka tetap mengakui bahwa dalam Alkitab digital itu terdapat Firman Tuhan yang menjadi tuntunan dan landasan kehidupan mereka.

Meskipun demikian, pada kenyataannya masih banyak juga segmen umat Kristen yang masih bertahan dengan penggunaan Alkitab versi buku. Pertama, para generasi tua yang belum terlalu akrab dengan media digital. Kedua, mereka yang secara geografis berada pada wilayah yang masih terbatas jaringan internet. Ketiga, mereka yang merasa sudah terbiasa menggunakannya sejak lama dan merasa lebih nyaman dengan itu.

Chen mengemukakan bahwa kelompok yang ketiga ini merasa "lebih dekat dan intim dengan Tuhan" melalui penggunaan Alkitab versi buku dibandingkan versi digital (Chen 2019). Mereka menemukan suasana yang luar biasa meneduhkan saat: 1) menyentuh lembaran-lembaran kertasnya, 2) berjelajah dari satu ayat ke ayat yang lain, 3) memberikan highlight pada ayat-ayat yang menyentuh dan menjadi pengingat di satu atau dua atau tiga atau bahkan berapa lama tahun sepanjang ayat itu masih ada, 4) memberikan catatan kecil di pinggiran-pinggiran bukunya. Pembaca Alkitab 
BONAFIDE: Jurnal Teologi dan Pendidikan Kristen

www.jurnal.sttissiau.ac.id/Volume 2/Nomor 1/Juni 2021/hal. 46-67

versi buku melakukan ini sambil membaca dengan perlahan, menghayatinya, meresapinya, menjadikannya darah dan daging bagian dari diri seutuhnya. Ini merupakan pengalaman yang luar biasa meneduhkan yang tidak didapatkan ketika menggunakan aplikasi Alkitab (Maryanti 2015).

Selain itu, kelebihan lain dari Alkitab versi buku adalah fungsinya yang tunggal hanya untuk menyajikan Firman Tuhan. Ini berbeda dengan Alkitab digital yang multifungsi yang bisa menggoda pembacanya kurang fokus saat membaca Alkitab. Mereka bisa tergoda untuk membuka aplikasi pesan, menerima panggilan telepon, bermedia sosial, dll (Klasis GPM Kota Ambon 2019.

Namun meskipun terjadi perbedaan respon terhadap kehadiran Alkitab digital, tampaknya kedua kelompok ini tetap melihat Alkitab, baik versi buku maupun digital, sebagai Firman Tuhan. Sebagai Firman Tuhan, Alkitab memiliki nilai kesucian sehingga disebut sebagai Kitab Suci. Keyakinan bahwa Alkitab merupakan kitab suci merupakan salah satu keyakinan dasar umat Kristen. Semua tulisan yang ada dalam Alkitab diyakini tulisan yang diilhamkan Allah sendiri. Sebab itu sama sekali tidak diragukan bahwa Alkitab merupakan satu-satunya Firman Allah (Nainggolan 2015). Bahkan ada yang meyakini bahwa yang diilhamkan bukan hanya makna, berita atau kata, melainkan sampai kepada proses penulisan. Makna ilham ilahi itu berlaku sehingga huruf-huruf itu disebut suci (hiera grammata) dan kitab itu disebut suci (2Tim. 3:15) (Sukono 2019).

Pernyataan ini menunjukkan bahwa makna suci pada Alkitab bukan hanya terletak pada isinya, tapi juga pada medianya. Pada Alkitab versi buku, bukunya itu 
BONAFIDE: Jurnal Teologi dan Pendidikan Kristen

www.jurnal.sttissiau.ac.id/Volume 2/Nomor 1/Juni 2021/hal. 46-67

sendiri sebagai media telah dianggap suci. Hal itu nampak seperti digambarkan oleh Maryanti di atas bagaimana pembaca Alkitab versi buku membaca dengan hati-hati dan bisa mendapatkan suasana meneduhkan. Suasana ini nampaknya melahirkan ikatan emosional antara pembaca dengan Alkitab.

Pertanyaannya, jika media Alkitab versi buku yaitu buku dianggap suci, apakah media Alkitab digital yaitu digital itu sendiri juga tetap dianggap suci? Jika tetap dianggap suci maka berarti tidak ada pergeseran makna kesucian Alkitab dari versi buku ke versi digital. Namun jika media digital tidak dianggap suci maka berarti telah terjadi pergeseran makna Alkitab sebagai kitab suci bahwa yang dianggap suci hanya isinya saja, bukan medianya. Pertanyaan selanjutnya, jika hanya isinya yang dianggap suci, apakah Alkitab digital memiliki otoritas yang sama dengan Alkitab versi buku bagi penggunanya? Kedua pertanyaan inilah yang ingin penulis temukan jawabannya melalui penelitian ini.

Ada tiga penelitian menarik terkait dengan topik ini. Pertama adalah penelitian Affandi (2018) yang memaparkan betapa pentingnya di era digital ini gereja memanfaatkan media digital dalam penatalayanan gereja yang disebutnya sebagai 'digital ekklesiologi'. Kedua adalah karya Dwiraharjo (2020) yang mencoba meletakkan dasar teologis penggunaan media digital gereja dalam pelaksanaan ibadah online pada masa pandemi covid-19 (Dwiraharjo 2020). Tidak ketinggalan karya Camerling dkk (2020) yang mengemukakan betapa pentingnya gereja menggunakan media digital untuk menjalankan misi. 
BONAFIDE: Jurnal Teologi dan Pendidikan Kristen

www.jurnal.sttissiau.ac.id/Volume 2/Nomor 1/Juni 2021/hal. 46-67

Ketiga tulisan tersebut pada intinya menyatakan pentingnya gereja memanfaatkan media digital. Selain karena gereja sudah sulit untuk menghindari serbuan arus teknologi informasi, media digital juga memiliki banyak kelebihan yang dapat memudahkan gereja menjalankan panggilan misinya. Meskipun demikian, ketiga tulisan ini belum spesifik membahas tentang penggunaan Alkitab digital sebagai bagian dari respon gereja terhadap perkembangan teknologi informasi. Tulisan ini akan menambah diskursus mengenai topik gereja dan media digital.

Subyek penelitian yang dilibatkan adalah anak-anak muda. Widhyharto menggambarkan bahwa kaum muda sangat dekat dengan dunia digital. Di Indonesia, peningkatkan penetrasi internet tidak lepas dari pengaruh penggunaan media sosial oleh kaum muda. Bahkan mereka yang lahir setelah tahun 1980, oleh sebuah hasil penelitian di India, disebut sebagai digital natives dan berperan sebagai e-agents of change (Widhyharto 2014). Sebab itu penelitian tentang penggunaan Alkitab digital baiknya dilakukan di kalangan orang muda Kristen. Penelitian ini mengambil lokasi di kota Luwuk, kabupaten Banggai, Propinsi Sulawesi Tengah.

\section{METODE PENELITIAN}

Metode yang digunakan adalah studi komparatif sebagai bagian dari metode kuantitatif. Aswarni Sudjud menjelaskan bahwa penelitian komparasi digunakan untuk menemukan persamaan-persamaan dan perbedaan-perbedaan mengenai benda, orang, prosedur kerja, atau ide-ide. Metode ini juga dapat membandingkan kesamaan pandangan dan perubahan-perubahan pandangan 
BONAFIDE: Jurnal Teologi dan Pendidikan Kristen

www.jurnal.sttissiau.ac.id/Volume 2/Nomor 1/Juni 2021/hal. 46-67

orang, grup, atau negara, terhadap kasus, orang, peristiwa, atau ide-ide. (dalam Arikunto 2012).

Hal yang ingin dibandingkan dalam penelitian ini adalah makna suci pada penggunaan Alkitab versi buku dan Alkitab versi digital untuk menemukan kemungkinan telah terjadinya perubahan atau pergeseran makna Alkitab sebagai sebagai kitab suci pada penggunaan Alkitab digital. Penggunaan Alkitab versi buku dan versi digital merupakan variabel independen sedangkan makna kitab suci merupakan variabel dependen. Menurut Sugiyono dalam penelitian komparasi diperlukan variabel kontrol yaitu variabel yang dikendalikan atau dibuat konstan sehingga pengaruh variabel independen terhadap variabel dependen tidak dipengaruhi oleh faktor yang tidak diteliti (Sugiyono 2018). Variabel kontrol yang digunakan adalah isi dan media Alkitab buku maupun digital. Dengan adanya variabel kontrol ini maka pergeseran makna Alkitab sebagai kitab suci pada penggunaan Alkitab digital dapat diketahui.

Data diambil dengan kuesioner dengan skala Likert dengan pilihan jawaban Sangat Setuju (SS), Setuju (S), Ragu-ragu (R), Tidak Setuju (TS), Sangat Tidak Setuju (TS). Responden diambil secara acak melalui pertemanan di Facebook dengan peneliti melalui akun Ermin Mosooli. Asumsinya, jika orang muda Kristen biasa menggunakan media sosial kemungkinan besar mereka sudah biasa menggunakan aplikasi Alkitab. Sampel diambil dengan teknik cluster random sampling. Dari pertemanan di Facebook tersebut sampel yang diambil secara acak pada teman muda yang berdomisili di kota Luwuk dan sekitarnya 
BONAFIDE: Jurnal Teologi dan Pendidikan Kristen

www.jurnal.sttissiau.ac.id/Volume 2/Nomor 1/Juni 2021/hal. 46-67

\section{HASIL PENELITIAN}

Penelitian ini melibatkan 26 responden dengan usia 18-35 tahun, berdomisili di kota Luwuk dan sekitarnya, dan mengaku sudah biasa menggunakan Alkitab digital. Hasil penelitian menunjukkan bahwa telah terjadi pergeseran makna Alkitab sebagai kitab suci di kalangan anak-anak muda di kota Luwuk sekitarnya. Secara umum responden mengakui bahwa isi Alkitab versi buku maupun Alkitab versi digital sama-sama suci, meskipun ada sedikit penurunan makna kesucian pada Alkitab versi digital. Pergeseran secara signifikan nampak pada pandangan responden mengenai kesucian media Alkitab versi buku ke versi digital. Sebagian besar responden mengakui media Alkitab versi buku lebih suci dibandingkan media Alkitab versi digital.

Gambar 1. Rangkuman Hasil Penelitian:

Pergeseran Makna Kesucian Alkitab dari Versi Buku ke Versi Digital
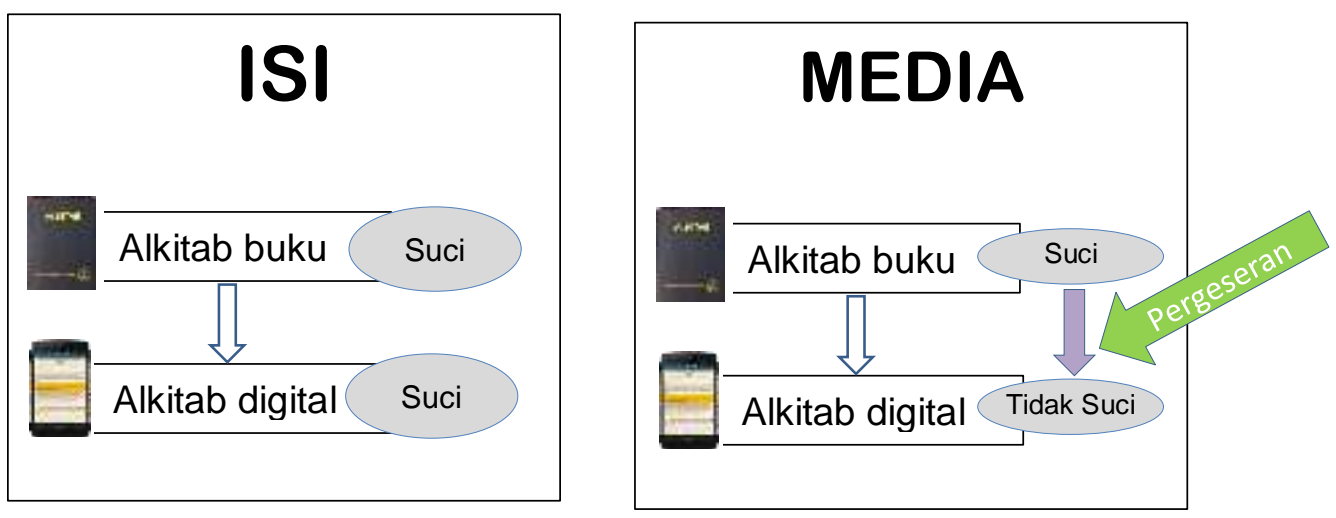

Berikut uraiannya berdasarkan delapan poin pertanyaan yang membandingkan Alkitab buku dan Alkitab digital. 
BONAFIDE: Jurnal Teologi dan Pendidikan Kristen

www.jurnal.sttissiau.ac.id/Volume 2/Nomor 1/Juni 2021/hal. 46-67

\section{Pergeseran Makna Kesucian Isi Alkitab dari Versi Buku ke Versi Digital}

Gambar 2. Perbandingan pandangan:

Alkitab suci karena berisi Firman Tuhan
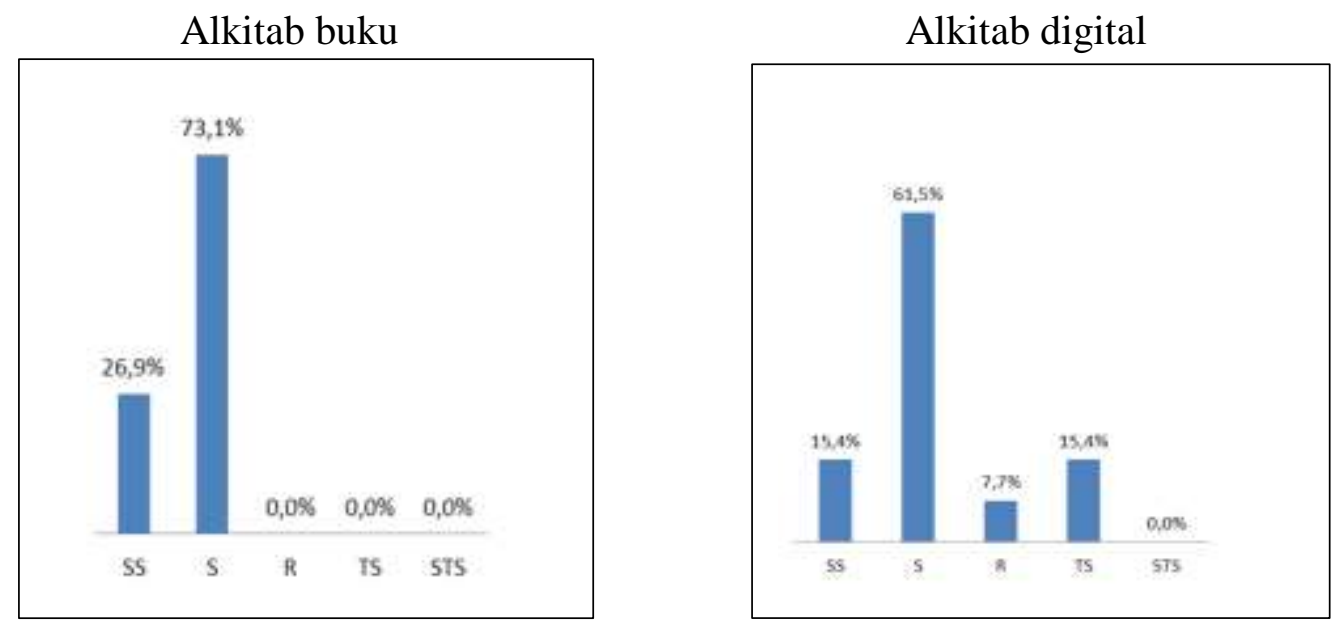

Dari Gambar 2 di atas nampak tidak terjadi pergeseran signifikan dalam pandangan responden mengenai kesucian isi Alkitab karena berisi Firman Tuhan, dari versi buku ke versi digital. Selisih antara pilihan dominan responden "Setuju" hanya $11,6 \%$.

Tabel 2. Perbandingan pandangan:

Alkitab suci karena isinya diilhamkan Allah

Alkitab buku

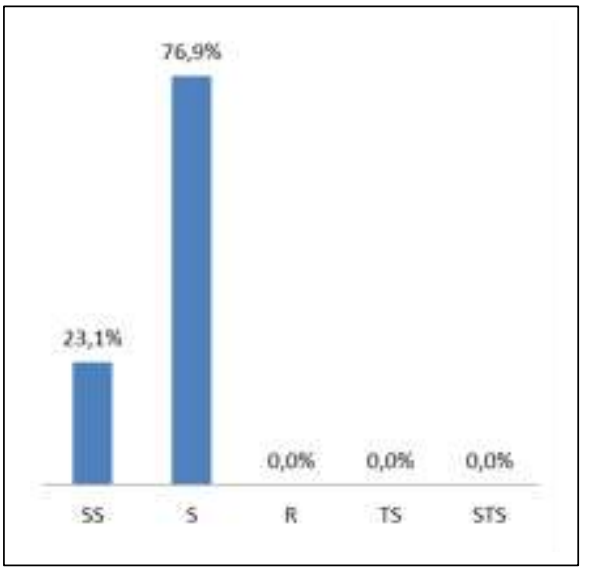

Alkitab digital

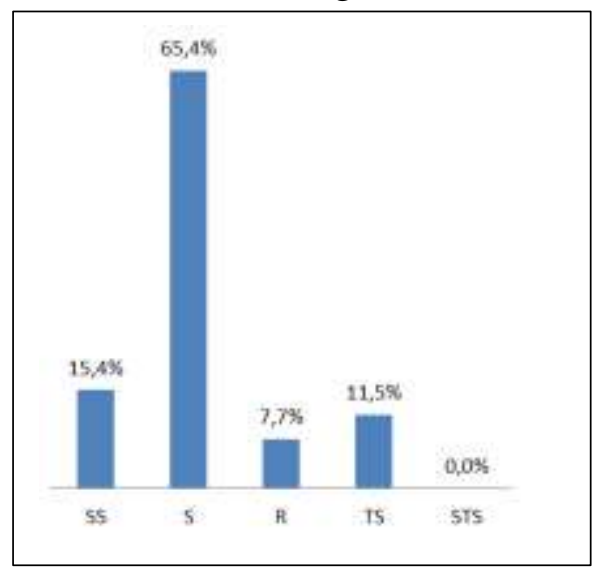


Pada Tabel 2 pergeseran pandangan mengenai kesucian Alkitab karena isinya diilhamkan Allah, dari Alkitab buku ke Alkitab digital, hanya sedikit. Pilihan dominan responden adalah Setuju dengan selisih $11,5 \%$.

Tabel 3. Perbandingan pandangan:

Alkitab suci karena isinya bermanfaat untuk mengajar dan memperbaiki kelakuan
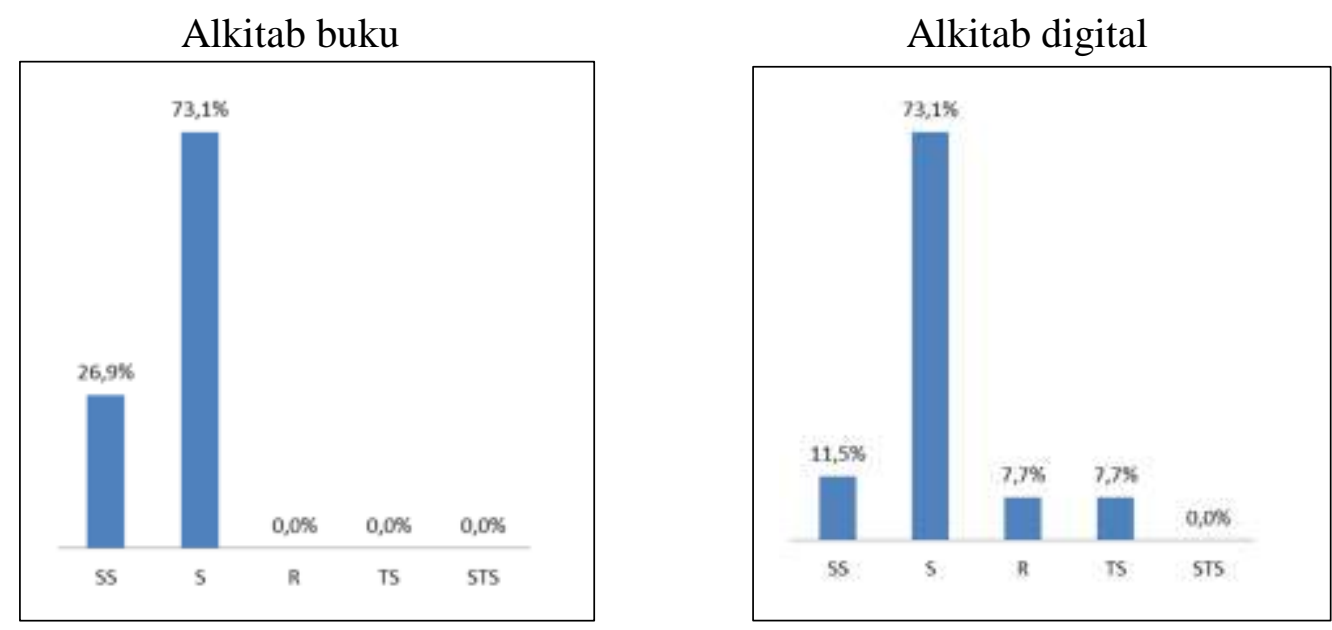

Tabel 4. Perbandingan pandangan:

Alasan membaca Alkitab suci karena isinya Firman Tuhan
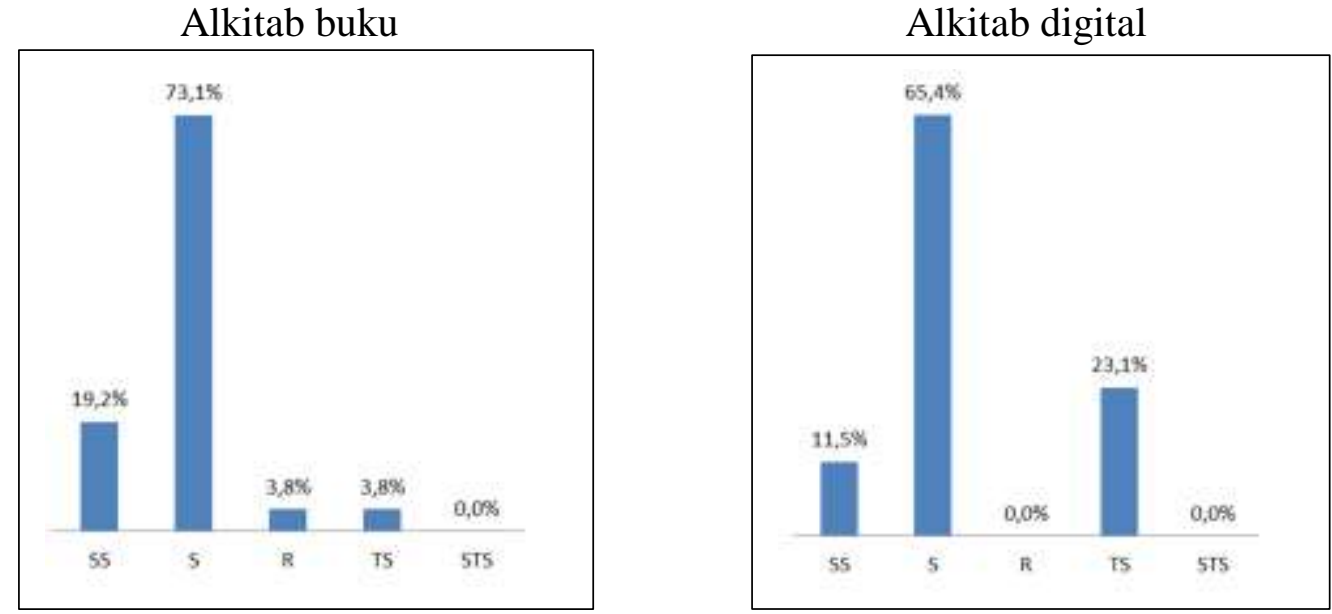
BONAFIDE: Jurnal Teologi dan Pendidikan Kristen

www.jurnal.sttissiau.ac.id/Volume 2/Nomor 1/Juni 2021/hal. 46-67

Pada Tabel 3 pergeseran pandangan mengenai kesucian Alkitab karena karena isinya bermanfaat untuk mengajar dan memperbaiki kelakuan, dari Alkitab buku ke Alkitab digital, sangat sedikit. Pilihan dominan responden adalah Setuju dengan selisih 0\%. Perbedaan hanya tampak pada pillihan Sangat Setuju yang selisih $15,4 \%$. Artinya acara umum responden menerima bahwa isi Alkitab digital sama-sama suci karena bermanfaat untuk mengajar dan memperbaiki kelakuan.

Pada Tabel 4 pergeseran motivasi membaca Alkitab karena alasan berisi Firman Tuhan, dari Alkitab buku ke Alkitab digital, juga sangat sedikit. Pilihan dominan responden adalah Setuju dengan selisih 7,7\%. Namun demikian muncul pilihan Tidak Setuju sebanyak 23,1\% alasan membaca Alkitab digital, naik dari 19,3\% dari alasan membaca Alkitab buku. Namun secara umum dapat disimpulkan bahwa motivasi responden membaca Alkitab digital masih sama dengan motivasi membaca Alkitab buku, yaitu karena berisi Firman Tuhan.

Berdasarkan Tabel 1 - Tabel 4 dapat disimpulkan bahwa tidak ada pergeseran yang signifikan dalam pandangan responden mengenai kesucian isi Alkitab dari versi buku kepada versi digital. Responden secara umum menilai Alkitab digital tetap suci karena isinya adalah Firman Tuhan yang diilhamkan Allah dan bermanfaat untuk mengajar dan memperbaiki kelakuan.

\section{Pergeseran Makna Kesucian Media Alkitab dari Buku ke Digital}

Pada Tabel 5 tampak terjadi pergeseran yang sangat signifikan dalam pandangan responden mengenai motivasi mereka menyimpan Alkitab dengan baik, 
BONAFIDE: Jurnal Teologi dan Pendidikan Kristen

www.jurnal.sttissiau.ac.id/Volume 2/Nomor 1/Juni 2021/hal. 46-67

dari Alkitab buku ke Alkitab digital. Ada dua area pilihan dominan. Pertama, pada area Setuju turun tajam 50\% dari Alkitab buku 73,1\% ke Alkitab digital sebanyak 23,1\%. Kedua, pilihan Tidak Setuju muncul sebanyak 50\% pada Alkitab digital, naik 46,2\% dari Alkitab buku. Dari angka ini dapat disimpulkan bahwa secara umum responden menilai media Alkitab buku memiliki nilai kesucian lebih tinggi dari media Alkitab digital. Artinya, media Alkitab digital tidak sesuci Alkitab buku.

Tabel 5. Perbandingan:

Alasan menyimpan Alkitab dengan baik karena isinya Firman Tuhan
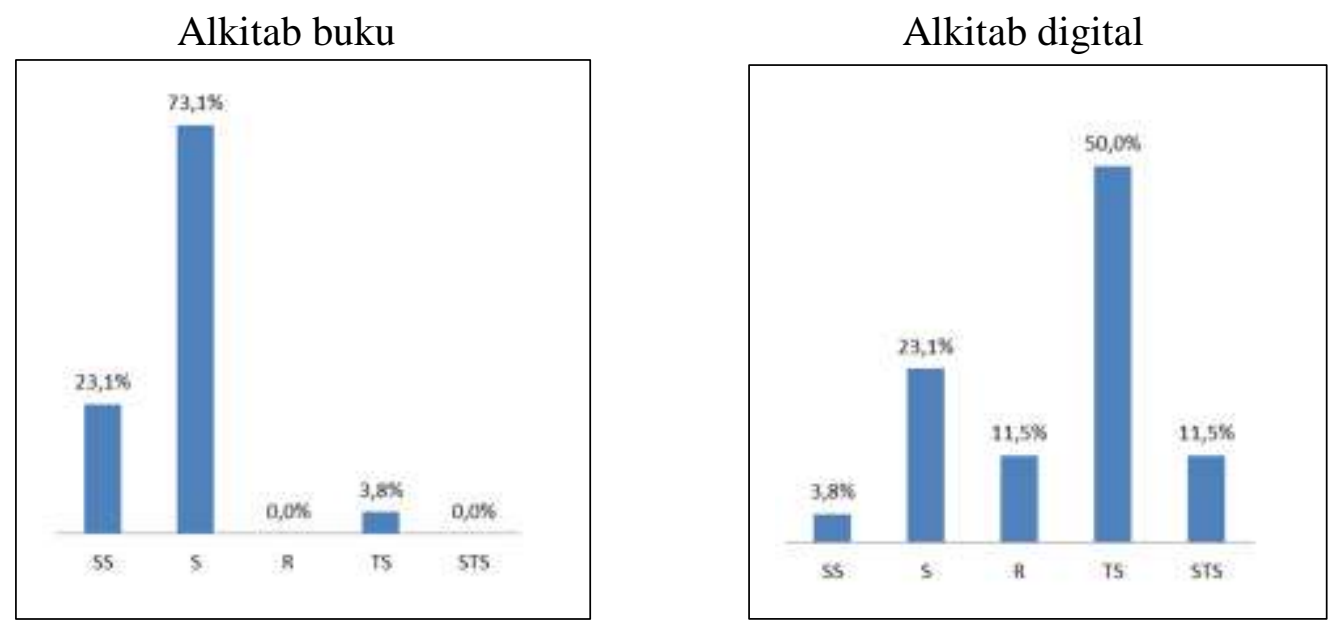

Tabel 6. Perbandingan pandangan:

Merasa bersalah bila Alkitab kotor atau rusak

Alkitab buku

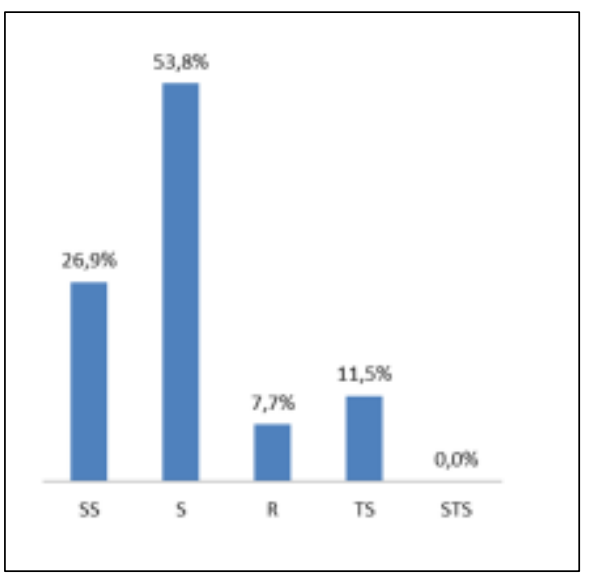

Alkitab digital

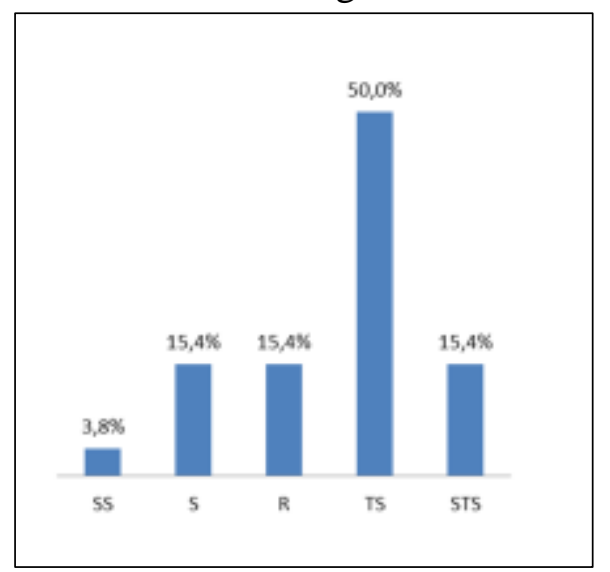


BONAFIDE: Jurnal Teologi dan Pendidikan Kristen

www.jurnal.sttissiau.ac.id/Volume 2/Nomor 1/Juni 2021/hal. 46-67

Pada Tabel 6 tampak terjadi juga pergeseran yang sangat signifikan mengenai perasaan responden bila media Alkitab mereka kotor atau rusak, dari Alkitab buku ke Alkitab digital. Ada tiga pilihan dominan. Pertama, pilihan Setuju turun tajam $38,4 \%$ dari Alkitab buku 53,8\% ke Alkitab digital sebanyak 15,4\%. Kedua, pilihan Tidak Setuju muncul sebanyak 50\% pada Alkitab digital, naik 38,6\% dari Alkitab buku sebanyak 11,5\%. Ketiga, pilihan Sangat Setuju pada Alkitab buku cukup tinggi yaitu sebesar 26,9\%, turun pada Alkitab digital sebanyak 23,1\% menjadi 3,8\%.

Dari angka ini dapat disimpulkan bahwa secara umum responden menilai media Alkitab buku memiliki nilai kesucian lebih tinggi dari media Alkitab digital karena itu mereka merasa bersalah bila Alkitab buku kotor atau rusak, dibandingkan media Alkitab digital.

Tabel 7. Perbandingan pandangan:

Merasa lebih tenang bila Alkitab berada di dekatnya pada saat sedih
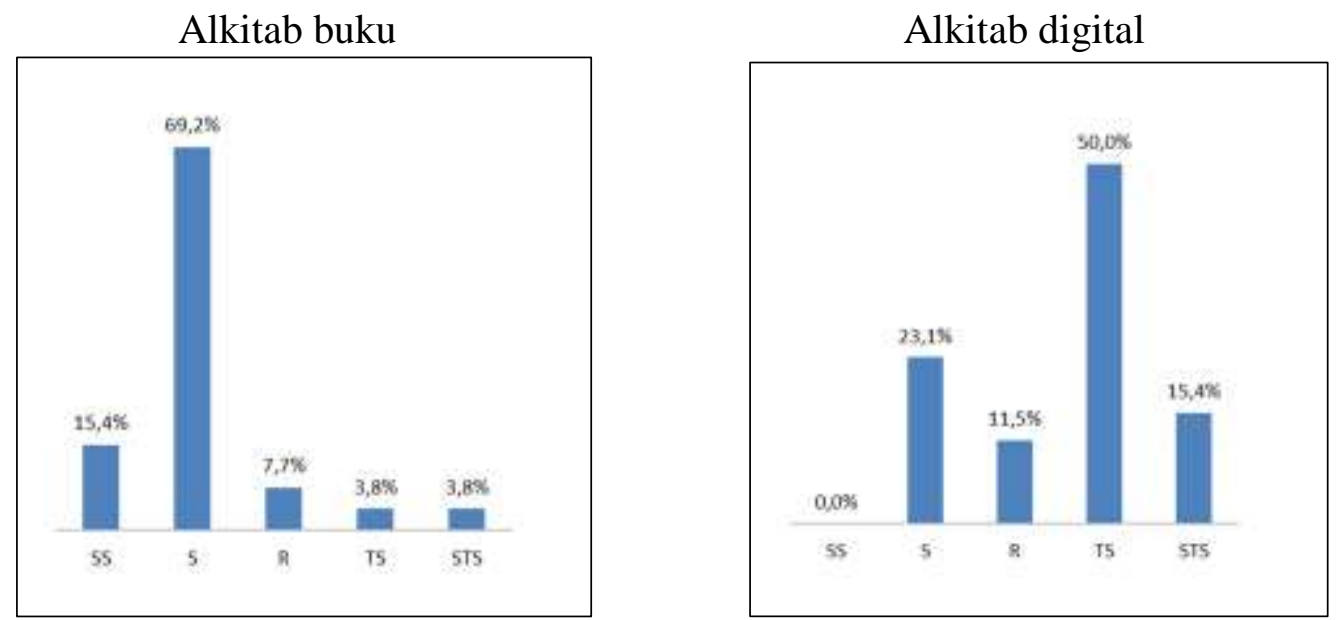

Pada Tabel 7 tampak terjadi pergeseran yang sangat signifikan mengenai perasaan responden bila media Alkitab berada di dekat mereka pada saat sedih, dari 
BONAFIDE: Jurnal Teologi dan Pendidikan Kristen

www.jurnal.sttissiau.ac.id/Volume 2/Nomor 1/Juni 2021/hal. 46-67

Alkitab buku ke Alkitab digital. Ada dua pilihan dominan. Pertama, pilihan Setuju turun tajam 45,1\% dari Alkitab buku 69,2\% ke Alkitab digital sebanyak 23,1\%. Kedua, pilihan Tidak Setuju muncul sebanyak 50\% pada Alkitab digital, naik 46,2\% dari Alkitab buku sebanyak 3,8\%. Dari angka ini dapat disimpulkan bahwa secara umum responden menilai media Alkitab buku memiliki nilai kesucian sebagai Firman Tuhan yang membuat mereka merasa lebih tenang di saat sedih, dibandingkan media Alkitab digital.

Tbel 8. Perbandingan pandangan:

Merasa mendapatkan kekuatan bila Alkitab berada di dekatnya pada saat sakit
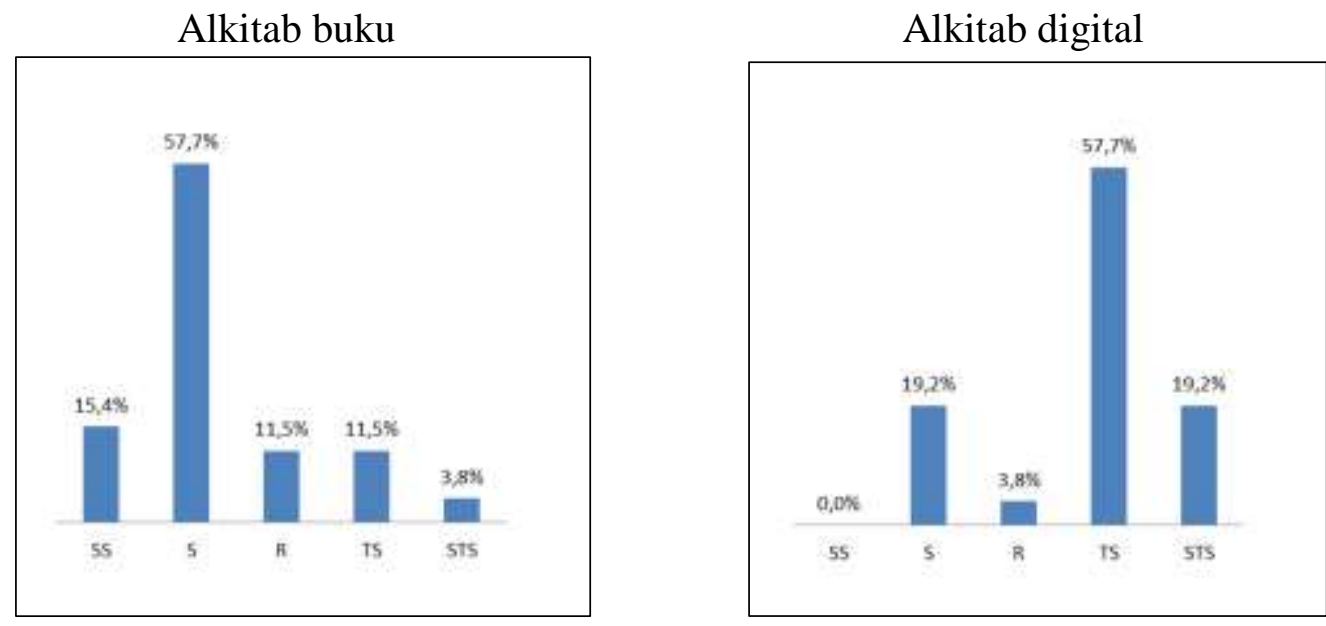

Pada Tabel 7 tampak terjadi pergeseran yang sangat signifikan mengenai perasaan responden bila media Alkitab berada di dekat mereka pada saat sakit, dari Alkitab buku ke Alkitab digital. Pilihan Setuju pada Alkitab buku sama banyak dengan pilihan Tidak Setuju pada Alkitab digital, yaitu sebesar 57,7\%. Pilihan Sangat Tidak Setuju juga muncul secara signifikan pada Alkitab digital yaitu sebesar 19,2\%, dibandingkan pilihan yang sama yang Alkitab buku yang hanya 3,8\%. Dari angka ini dapat disimpulkan bahwa secara umum responden menilai media Alkitab 
BONAFIDE: Jurnal Teologi dan Pendidikan Kristen

www.jurnal.sttissiau.ac.id/Volume 2/Nomor 1/Juni 2021/hal. 46-67

buku sebagai Firman Tuhan mampu memberi mereka kekuatan di saat sakit dibandingkan Alkitab digital.

Dengan demikian, dari Tabel 5 - Tabel 8 dapat disimpulkan bahwa terjadi pergeseran cukup signifikan dalam pemahaman responden mengenai kesucian media Alkitab, dari media buku ke media digital. Media buku memiliki nilai yang besar dalam menghadirkan makna kesucian Alkitab sebagai Firman Tuhan kepada responden, dibandingkan media digital.

\section{PEMBAHASAN}

\section{Keunggulan Alkitab Versi Buku}

Hal pertama yang menarik dari hasil penelitian ini adalah temuan bahwa di mata responden nilai kesucian Alkitab versi buku tetap memiliki keunggulan tersendiri. Fakta ini sesungguhnya bisa dijelaskan, paling tidak, dari tiga faktor.

Pertama, faktor kebiasaan. Seperti digambarkan oleh Maryanti bahwa pembaca Alkitab versi buku bisa merasakan suasana yang meneduhkan saat membaca Alkitab mereka (Maryanti 2015). Bagi orang Kristen sejak kecil, kegiatan membaca Alkitab tentu dimulai dari kecil. Mereka tumbuh dalam komunitas yang mengajarkan bahwa Alkitab buku itulah kitab suci orang Kristen. Jika merujuk pada teori konstruksi sosial Berger dan Luckmann, realitas sosial merupakan hasil sebuah konstruksi sosial. Teori ini berada di antara teori fakta sosial dan definisi sosial. Teori fakta sosial melihat bahwa persepsi manusia sangat dipengaruhi oleh struktur sosial yang eksis, seperti institusi, norma, struktur dan lembaga sosial mempengaruhi perilaku individu manusia (dalam Mustakim et al. 2020). Pemahaman responden 
BONAFIDE: Jurnal Teologi dan Pendidikan Kristen

www.jurnal.sttissiau.ac.id/Volume 2/Nomor 1/Juni 2021/hal. 46-67

mengenai kesucian Alkitab dipengaruhi oleh sosialisasi gereja tempat mereka berafiliasi atau pun gereja lainnya.

Kedua, adanya doktrin atau pandangan teologi dalam agama Kristen yang memberi penghargaan yang tinggi kepada Alkitab. Di kalangan kaum Injili hidup dengan kuat doktrin kecukupan (sufficiency) Alkitab. Doktrin ini, seperti dipaparkan Reynaldi, secara material menegaskan bahwa Alkitab tidak perlu dan tidak dapat ditambahkan lagi dengan apa pun dan secara formal kesanggupan Alkitab untuk menafsirkan dirinya sendiri tanpa bantuan eksternal (Reynaldi 2019). Di kalangan kaum Reformasi dipegang kuat prinsip sola Scriptura. Prinsip utama dalam sola Scriptura adalah prinsip yang menjadikan Alkitab Firman Allah sebagai pusat satu-satunya instrumen Allah untuk memahami dan memberitakan kebenaran Pribadi dan KaryaAllah (Supriadi 2019).

Walaupun belum ada penelitian yang membuktikan hubungan langsung antara doktrin ini dengan pengakuan yang tinggi kepada Alkitab versi buku, tapi pengaruhnya tidak bisa dipungkiri. Paling tidak selama ratusan tahun ketika orang bicara tentang Alkitab yang demikian, mereka menunjuk kepada Alkitab versi buku. Jadi selama itu orang selalu mengaitkan doktrin kecukupan Alkitab maupun prinsip sola scriptura dengan Alkitab versi buku.

Ketiga, Alkitab buku hanya memiliki satu fungsi. Berbeda dengan Alkitab digital yang medianya bersifat multifungsi, Alkitab buku hanya berfungsi sebagai media Firman Tuhan. Orang yang memegang Alkitab buku akan fokus untuk membaca Firman Tuhan dan kecil kemungkinan untuk terusik melakukan aktifitas 
BONAFIDE: Jurnal Teologi dan Pendidikan Kristen

www.jurnal.sttissiau.ac.id/Volume 2/Nomor 1/Juni 2021/hal. 46-67

lain saat membaca Alkitab.

Ketiga hal ini berkontribusi signifikan kepada tingginya posisi Alkitab buku di mata para penggunanya. Namun ke depan, jika orang makin terbiasa, sangat mungkin nilai aplikasi Alkitab digital pun akan naik.

\section{Keutamaan Alkitab Digital: Kesucian Isi dan Kemudahan Penggunaannya}

Hal kedua yang menarik dari hasil penelitian ini terkait dengan penggunaan Alkitab digital adalah bahwa meskipun responden menilai bahwa media digital tidak sesuci media buku, tetapi mereka tetap mengakui bahwa isinya adalah Firman Tuhan yang diilhamkan Allah dan bermanfaat untuk mengajar serta memperbaiki kelakuan. Artinya, bagi responden isi lebih penting dari media.

Tampaknya ini akan menjadi kencenderungan baru dalam kehidupan umat Kristen di tengah derasnya arus digitalisasi yang memasuki kehidupan masyarakat. Kemungkinan pengguna Alkitab digital akan terus naik. Bagi penggunanya media yang digunakan seperti smartphone, tablet, dan lain sejenis itu tetap tidak dianggap suci. Media digital dipandang hanya sebagai alat biasa karena yang penting bukanlah medianya tapi isinya. Jadi media digital pada Alkitab digital tidak akan bersaing dengan Alkitab buku. Alkitab digital tetap pada daya tariknya tersendiri yaitu penggunaannya yang lebih mudah dan praktis.

Dari sisi historis, perkembangan media Alkitab adalah sebuah fenomena yang wajar. Seperti digambarkan Kondoj bahwa media Alkitab berkembang mulai dari tradisi lisan ke berbagai versi tulisan kuno (Kondoj 2017) dan kemudian ke versi 
BONAFIDE: Jurnal Teologi dan Pendidikan Kristen

www.jurnal.sttissiau.ac.id/Volume 2/Nomor 1/Juni 2021/hal. 46-67

buku cetak (Britannica n.d.). Alkitab digital adalah perkembangan terbaru media Alkitab.

Dalam perkembangan dari tradisi lisan menuju versi buku, meskipun melewati sebuah proses kanonisasi, hal yang paling penting dari Alkitab bagi umat Kristen adalah isinya. Seperti dikatakan Kia, dasar otoritas Alkitab adalah Alkitab itu sendiri mutlak benar dan kekal (Mzm. 119: 89-160), isinya sempurna (Mzm. 19:7), dan perintahnya suci, baik, benar (Rm. 7:12). Dari sini jelas bahwa otoritas Alkitab itu berpusat pada kebenaran, kekekalan dan perintah Allah (Kia 2018), bukan pada medianya.

\section{Apakah Alkitab Digital Mengancam Kewibawaan Alkitab sebagai Kitab Suci?}

Jawabannya terhadap pertanyaan ini bisa ya bisa tidak. Pertama, jawabannya akan "ya" jika kewibawaan Alkitab dilihat secara utuh melekat pada isi dan media. Jika media buku pada Alkitab versi buku dianggap suci, maka kehadiran Alkitab Alkitab digital bisa dianggap mengancam kewibawaan Alkitab.

Kedua, jawabannya akan "tidak" jika kewibawaan Alkitab dilihat hanya pada isinya saja bahwa Alkitab berisi Firman Tuhan. Jadi medianya apa saja tidak akan mengganggu makna kewibawaan Alkitab bagi para penggunanya.

Dari hasil penelitian ini tampak bahwa meskipun para responden tidak menilai media Alkitab digital sesuci media Alkitab buku tetapi mereka tetap menggunakan dan menerima isinya sebagai Firman Tuhan. Dalam hal ini Alkitab digital tetap memiliki kewibawaan bagi mereka. 
BONAFIDE: Jurnal Teologi dan Pendidikan Kristen

www.jurnal.sttissiau.ac.id/Volume 2/Nomor 1/Juni 2021/hal. 46-67

Kelompok Kristen seperti ini kelak akan lebih mudah beradaptasi dengan perkembangan teknologi yang terus saja membanjiri kehidupan manusia, termasuk gereja. Di masa sekarang ini Alkitab digital merupakan sebuah perkembangan baru. Bisa saja ke depannya akan muncul lagi Alkitab dalam versi lain yang lebih kreatif dan inovatif. Hal itu mestinya tidak akan menurunkan makna kewibawaan Alkitab sebagai Firman Tuhan di mata para penggunanya.

\section{KESIMPULAN}

Kehadiran Alkitab digital telah membawa suasana baru dalam kehidupan umat Kristen. Di satu sisi ini merupakan bukti bahwa agama Kristen tetap mampu beradaptasi dengan perkembangan zaman. Firman Tuhan itu abadi. "Langit dan bumi akan berlalu, tetapi perkataan-Ku tidak akan berlalu” (Mat. 24:35). Hal yang berubah adalah cara dan media penyampaiannya.

Pergeseran makna kesucian Alkitab, dari Alkitab versi buku kepada versi digital, di kalangan orang muda menghadirkan sebuah fenomena cara beriman yang lebih substansial. Iman seharusnya didasarkan pada isi, bukan pada kulitnya. Sebab itu jika terjadi perubahan pada kulit, tidak perlu mengakibatkan resistensi yang berlebihan.

\section{DAFTAR PUSTAKA}

Afandi, Yahya. 2018. "Gereja Dan Pengaruh Teknologi Informasi 'Digital Ecclesiology." FIDEI: Jurnal Teologi Sistematika Dan Praktika 1 (2): 270-83. https://doi.org/10.34081/fidei.v1i2.12. 
BONAFIDE: Jurnal Teologi dan Pendidikan Kristen

www.jurnal.sttissiau.ac.id/Volume 2/Nomor 1/Juni 2021/hal. 46-67

Arikunto, Suharsimi. 2012. Prosedur Penelitian: Suatu Pendekatan Praktik (Edisi Revisi). Rineka Cipta. Revisi. Jakarta: PT. Rineka Cipta.

Berita Oikumene. 2016. "Dalam Gelombang Era Digital." Berita Oikumene, 2016. http://pgi.or.id/wp-content/uploads/2016/05/BO-Mei_upload.pdf.

Britannica, The Editors of Encyclopaedia. n.d. "Gutenberg Bible | Description, History, \& Facts." In Britannica. Accessed May 30, 2021. https://www.britannica.com/topic/Gutenberg-Bible.

Camerling, Yosua Feliciano, Mershy Ch. Lauled, and Sarah Citra Eunike. 2020. "Gereja Bermisi Melalui Media Digital Di Era Revolusi Industri 4.0." Visio Dei: Jurnal Teologi Kristen 2 (1): 1-22. https://doi.org/10.35909/visiodei.v2i1.68.

Chen, Vivien. 2019. "Pandangan Anak Muda Nasrani Terhadap Alkitab Elektronik NewsLab UAJY." Http://Newslab.Uajy.Ac.Id/. 2019. http://newslab.uajy.ac.id/2019/12/09/pandangan-anak-muda-nasrani-terhadapalkitab-elektronik/.

Dwiraharjo, Susanto. 2020. "Konstruksi Teologis Gereja Digital: Sebuah Refleksi Biblis Ibadah Online Di Masa Pandemi Covid-19." EPIGRAPHE: Jurnal Teologi Dan Pelayanan Kristiani 4 (1): 1-17. https://doi.org/10.33991/epigraphe.v4i1.145.

Kia, A Dan. 2018. "Kajianteologis-Pedagogis Menyangkut Keyakinan Guru PAK Memahami Otoritas Alkitab Dalam Pengajarannya." Jurnal Shanan 2 (1): 3955. https://doi.org/10.33541/shanan.v2i1.1500.

Klasis GPM Kota Ambon. 2019. “Alkitab Digital vs Alkitab Fisik, Manakah Yang Layak Digunakan?” Klasis GPM Kota Ambon. 2019. https://artikel.klasiskotaambon.org/alkitab-digital-vs-alkitab-fisik-manakahyang-layak-digunakan/.

Kondoj, Brando V. 2017. "Mencari Jejak-Jejak Autograf Perjanjian Lama Di Dalam Septuaginta." Veritas: Jurnal Teologi Dan Pelayanan 16 (1): 33-46. https://doi.org/10.36421/veritas.v16i1.9.

Maryanti, Antonetta. 2015. “Alkitab Digital vs Buku Alkitab .” Kompasiana.Com. 2015.

https://www.kompasiana.com/yantilengo/563bfb416323bd89048b4567/alkitabdigital-vs-buku-alkitab?page=all.

Mustakim, Mustakim, Ishomuddin Ishomuddin, Wahyudi Winarjo, and Khozin Khozin. 2020. "Konstruksi Kepemimpinanan Atas Tradisi Giri Kedaton Sebagai Identitas Sosial Budaya Masyarakat Kabupaten Gresik." Media Komunikasi FPIPS 19 (1): 11-27.

Nainggolan, Batholomeus Diaz. 2015. "Interpretasi: Dunia Mepertanyakan Apakah Alkitab Benar Diilhamkan Allah?” Jurnal Koinonia 7 (1): 13-21. 
BONAFIDE: Jurnal Teologi dan Pendidikan Kristen

www.jurnal.sttissiau.ac.id/Volume 2/Nomor 1/Juni 2021/hal. 46-67

Reynaldi, Christian. 2019. "Kitab Suci, Gereja, Dan Otoritas: Harmonisasi Doktrin Kecukupan Alkitab Dengan Sejarah Gereja." Veritas: Jurnal Teologi Dan Pelayanan 18 (1): 1-13. https://doi.org/10.36421/veritas.v18i1.318.

Sugiyono. 2018. Metode Penelitian Kuantitatif, Kualitatif, Dan R\&D. Bandung: Alfabeta.

Sukono, Djoko. 2019. "Alkitab: Penyataan Allah Yang Diilhamkan." PASCA : Jurnal Teologi Dan Pendidikan Agama Kristen 15 (1): 28-34. https://doi.org/10.46494/psc.v15i1.66.

Supriadi, Made Nopen. 2019. "Tinjauan Teologis Terhadap Pendekatan Evidensialist Dalam Perspektif Reformed Theology." Manna Rafflesia 5 (2): 128-36. https://doi.org/10.38091/man_raf.v5i2.106.

Susanto, Budi. 2018. "Pembangunan Komunitas Digital Untuk Gereja, Lembaga, Dan Komunitas Kristen.” Www.Researchgate.Net. 2018. https://doi.org/10.13140/RG.2.2.36024.80643.

Widhyharto. 2014. “Kebangkitan Kaum Muda Dan Media Baru." Jurnal Studi Pemuda 3 (2): 144-46. https://doi.org/10.22146/studipemudaugm.32030. 